\title{
Forceful Federalism against American Racial Inequality
}

Abstract: Why, many Americans rightly ask, can material racial inequality and widespread segregation still persist fifty years after the enactment of key civil rights legislation and eight years after the election of an African American to the nation's highest office? Many from outside the United States pose similar questions about modern America. The explanation, I argue lies with inconsistent and fluctuating levels of federal engagement to building material racial equality. National engagement fluctuates because it is energetically resisted and challenged, by opponents of racial progress. This vulnerability to disruption is exposed by varying strategies of resistance, some fiscal, some violent, some judicial, some desultory and some combining violent protest against change with local electoral triumphs for anti-reformers. Public resistance to employing national resources to reduce inequality encouraged a de-racialization strategy amongst many African American candidates for elected office who opt to de-emphasise issues of racial inequality in campaigns and in office. Whatever the means, the effect is uniform: the slowing down or outright death of federal civil rights activism.

Keywords: Federalism; race; inequality; judiciary; reform; America 


\section{Forceful Federalism against American Racial Inequality}

"I knew that if the federal government made it a law it'd have to be followed." 1

It would be difficult to conceive of a more glaring instance of democratic dysfunction than the politics of contemporary American racial inequality. Although the Clinton-Trump contest includes some discussion of the issue (provoked by Trump's strong intervention), mostly the enduring problem of material racial inequality is side-lined in presidential debates, belittled by the dominant GOP in Congress whose Tea Party influences include a thinly disguised racism, attacked by the 5 justice majority in the Supreme Court through such rulings as Shelby and Ricci, and horribly evoked in police-African American relations. The rise of the Black Lives Matter civil rights movement and the effort to inject issues of wealth inequality and reparations into the 2016 presidential debate signal the political salience of persistent racial inequality. But this salience is highly skewed as it is not an issue of concern to Republicans or to many white voters (Tesler 2016); in addition America's electorate is exceptionally polarized (McCarty 2015) including on racial issues.

In June 2014, the Atlantic Monthly devoted almost its entire issue to an article by TaNehisi Coates entitled “The Case for Reparations.” Why, one hundred and fifty years after America's poisonous Civil War and fifty years after the enactment, despite prevarication and racist opposition, of federal laws proscribing racial discrimination would a pre-eminent magazine give such an expansive article lead billing? Coates was writing three months before the police killing of Michael Brown in Ferguson, Missouri. Since Brown's death a civil rights movement, 'Black Lives Matter' has developed, and the litany of subsequent and previous police deaths of African Americans, and the murders of the Emanuel/Charleston

\footnotetext{
${ }^{1}$ Quote from one of the first African American textile workers in SC after passage of CRA Title VII, cited in Wright (2013: 110).
} 
Nine (by racist hater Dylann Roof) has forced the issue of enduring racial inequality onto Americans'shifting national agenda.

But what enabled Coates to write about reparations is the scale and endurance of America's material racial inequalities, which predate the recent outrages in the enforcement of the rule of law by local police forces. Why, many Americans rightly ask, can material racial inequality and widespread segregation still persist fifty years after the enactment of key civil rights legislation and eight years after the election of an African American to the nation's highest office? Many from outside the United States pose similar questions about modern America.

A key explanation, I argue lies with inconsistent and fluctuating levels of federal engagement to building material racial equality (Francis 2014). This federal activism has two dimensions. First, enforcement of policy is weak. Many of the institutional reforms and national standard needed for amelioration are often given insufficient resources for effective implementation. Second, national engagement fluctuates because it is energetically resisted and challenged, by opponents of racial progress - opponents composed along a continuum of the virulently white racist to the moderate voter unhappy with any sort of race targeted programmes (King and Smith 2011, 2014). This vulnerability to disruption is exposed by varying strategies of resistance, some fiscal, some violent, some judicial, some desultory and some combining violent protest against change with local electoral triumphs for antireformers. Public resistance to employing national resources to reduce inequality encouraged a de-racialization strategy amongst many African American candidates for elected office who opt to de-emphasise issues of racial inequality in campaigns and in office (Gillespie 2012, Gillion 2016, Greer 2013, Pinderhughes 2014, Price 2016, Spence 2015, Stout 2015, Tate 1994, 2003, Wright Rigueur 2015). Whatever the means, the effect is uniform: the slowing down or outright death of federal civil rights activism. 
Forceful federalism and reform.

Progress toward material racial equality rests in no small part on forceful American federal government policy galvanized into action by the civil rights protest movement, and then on enforcement. But the post-civil rights federal dynamic to desegregate and to advance material racial equality peaked in the 1970s, a mere ten years after the enactment of fundamental laws to institutionalize equal rights of citizenship.

Federal activism is necessary because material racial inequality is in part sustained by inter-connected institutions of discrimination which reinforce each other. Because racial inequality is a self-reinforcing system, the American federal government needs a range of measures focused on reducing material racial inequality. Schooling opportunities are closely related to where households live, with residential segregation reflected in school district options. Health outcomes are also highly unequal racially (Dimick et al 2013). Translating education and training into a career depends on equality of opportunity or a level playing field in labor market recruitment but audit tests show continued discrimination in labour markets. In turn labor market incomes structure the possibility of making savings and building household assets. Desegregation matters to material racial inequality since residential segregation correlates with inequality and unequal outcomes. Half-hearted responses to discrimination and segregation enable persistent socio-economic disparities to fall on a black-white basis, segregated schooling and housing feed into unfair and limited labour market opportunities, compounded by unequal health care, credit markets conditions and a problematic criminal justice system (Campbell and Schoenfeld 2013, Fortner 2015, Gottschalk 2006, 2014, Garland 2010, Lacey and Soskice 2015, Miller 2016, Murakawa 2014). Shifting this system toward equitable outcomes is impossible at the local level; 
competing local jurisdictions are structurally organized against redistribution and toward economic development policies, together making up 'city limits' (Peterson 1981). And if the federal state stops or slows down in one policy area - for example, lacklustre school desegregation - this inertia is contagious to other institutions in need of measures addressing material racial inequality.

The trajectory of inequality.

Data from the Great Recession (2007-08) reveal disproportionate racial effects - for example unemployment rates, after controlling for education, differ significantly by race. These gaps have widened over several decades. Results based on analysis of the Panel Survey of Income Dynamics show that in the 23 years prior to 2007, the wealth gap between African American and white households increased by $\$ 75,000$ (from $\$ 20,000$ to $\$ 95,000$ ) (Shapiro et al 2010). American federal policy was a key contributor to this growing disparity through such policies as reduced taxes on investment income and inheritance and through the way in which many policies - tax deductions for mortgages and retirement accounts - operate regressively. Reexamining these trends in 2013, the same researchers underline that the racial wealth gap is not a product of random patterns, behavioural quirks or lifestyle choices but is traceable to American federal policy and the "configuration of both opportunities and barriers in workplaces, schools, and communities that reinforce deeply entrenched racial dynamics in how wealth is accumulated" (Shapiro et al 2013). Using data from the continuing PSID annual survey to trace 1700 working age households between 1984 and 2009 the researchers identified a white-black wealth gap of just under a quarter of a million dollars $(\$ 236,500)$ by 2009. Factors such as how long in home ownership, household income, labor market participation, level of education and inherited wealth or financial support combine to explain 
the divergent patterns. Each factor makes a sizeable difference. But homeownership is a particularly powerful source of the racial wealth gap (Shapiro et al 2013: 3). These effects then feeds into how wealth is inherited - or not.

The Pew Research Center (2012) finds in 2005 the median net worth of white households was $\$ 134,992$; by 2009 this figure had dropped to $\$ 113,149$. For African American households the 2005 median net worth of households was $\$ 18,359$, a figure which plummets to $\$ 6,325$ in 2009 . And for Latino households the figures are $\$ 12,124$ in 2005 and $\$ 5,677$ in 2009. Fifteen per cent of white households had zero or negative wealth in 2009 . This figure compared with 35 per cent of African American and 31 per cent of Latino households. Pew's analysis shows not only the divergence in household wealth by race but the more severe decline endured by non-white households. Intergenerational economic mobility is limited. Using two sets of intergenerational data (which include large samples of African American families) with comprehensive measures of parents' earning, Mazumder (2014: 8) finds that "more than 50 per cent of blacks who start in the bottom quintile in the parent generation remain there in the child generation, but only 26 per cent of whites remain in the bottom quintile in both generations." His findings don't vary much when controlling for level of education. As Mazumder remarks these trends in income distribution show "no racial convergence."

The National Urban League's study in 2014 reports that unemployment rates for African American men still stand at double the white rate six years after the Recession - a greater discrepancy than existed in 1972 . Two researchers report that in 2013 , " 12.4 percent of black college graduates between the ages of 22 and 27 were unemployed" compared with 5.6 percent among all college graduates in this age group (Jones and Schmitt 2014: 1). 
How and why forceful federalism (and disengagement) matters.

The politics of racial inequality and hierarchy is foundational to the American polity. This means the content and administrative design of policy decisions is intrinsically affected by America's history of racial inequality (Anderson 2016, Johnson 2015). In the twentieth century this effect stretches from the familiar story of racial bias in the Social Security Act of 1935 and the racial redlining of mortgage insurance provision initiated in the New Deal era to the design of anti-discrimination labor market policy in the 1970s to the expansion of criminal justice incarceration since the 1980s to struggles about voter suppression in our own decade. Racial inequality and its politics suffuse all institutions and policies of American government. There is variation in the degree to which state institutions directly or indirectly, implicitly or explicitly express racial politics but the key point is that all are influenced in some way and to some degree by this legacy (Johnson 2015).

For example, the federal government was fundamental to the construction of modern white American households' wealth (Thurston 2015). The nineteenth century Homestead Act enriched and supplied a means for white householders to build wealth and prosper. The much vaunted '30 acres and a mule' promised to African Americans and which could have formed a comparable basis for asset accumulation was hollow. The campaign of demotion and segregation of black workers in federal bureaucracies launched by Woodrow Wilson in 1913 cut one African American's salary from $\$ 1400$ to $\$ 700$ as he was summarily, and without explanation, reduced from the grade of manager to messenger: not only did this discrimination smash his career but it reduced the household income and the prospects for his children and grandchildren (Davis 1915, King 2007). Such measures and other aspects of American federal policy notably university education opportunities in the GI Bill and the national subsidization of federal highway access to suburbs built white American household wealth in racially exclusionary ways. Disproportionate rates of white-black household wealth 
are not a result of 'natural' forces but arise from legacies of racism and identifiable American federal policy.

Progress toward material racial equality in American life since the 1960s is mixed. The Armed Forces for instance are integrated. But US prisons have become centers of disproportionate racial concentration. Residential housing evinces desegregation in many American cities but the trend is modest (Iceland, Weinberg and Steinmetz 2002, Ellen, 2007, Charles 2001, Logan and Stults 2011, Glaeser and Vigdor 2012, Reardon and Bischoff 2011). Segregation in public places is gone (Hochschild 1998) - a triumph for the extraordinary travails of Rosa Parks and countless others (Parks 1992, Theoharis 2013). In other areas such as schools, desegregation is reversing and no longer advancing toward integration (in part for demographic and policy reasons). The protection and enforcement of voting rights is dramatically transformed since 1965, yet aggressive efforts to limit African American and Latino voters' participation have dominated headlines since the Supreme Court's 2013 decision (Shelby County, Alabama v. Holder) that the VRA power of pre-clearance is unconstitutional - and it took concerted efforts of civil rights activists to enforce the VRA in the first place (Berman 2015). Instances of public acts or statements of racism are rarer (and subject to legal sanction, though far from unknown). Levels of racial inequality in university admissions and private workplaces by contrast seem stuck at thresholds set in the 1970s, beyond which there is little movement.

One determinant of these varying outcomes is the level of American federal policy and its enforcement. Scholars often remark on the comparative diffusion and lack of administrative force of America's national government. But in racial politics the federal government is never irrelevant and any imputed infirmity overlooks assistance to whites, and the decisions taken not to enlarge federal activism (as Kato 2015 explains in respect to failed federal anti-lynching laws). Without comprehensive and decisive national led intervention, 
of a sort that has occurred episodically, progress to equality is limited because in a fragmented federal political system, local resources are inadequate and local officials are often hostile to reform or if committed to change, often stymied by judicial rulings and/or local whites' violence. This motif runs from the middle of the $19^{\text {th }} \mathrm{C}$ to 2016 (Gerstle 2015). Undoubtedly, there is a weak national state in the US but this weakness is not merely about its limited policy instruments. Nor is weakness one dimensional - a lack of concern about racial inequality is a strength for holders of white privilege (King and Lieberman 2009, Sheingate 2009). Apparent federal weakness is also a reflection of the level of white violence reform encounters, compounded by a set of white public opinions set against federal action to forge change (Schwartzman 2016).

An example from New York City helps to illustrate the impediments facing federal activism to reduce material racial inequality. In October 2011, a federal judge, Nicholas Garaufis, ordered the NYC Fire Department immediately to reform its hiring practices because of the existing fire-fighters' racial profile. Judge Garaufis found that whereas close to fifty percent of NYC residents were African American, 98 percent of fire-fighters were white (Coleman 2011). The judge appointed a 'monitor' to oversee the department's recruitment, hiring and promotions practices in the ensuing ten years.

The fire department had to improve the diversity of its employee profile. In its graduating class, at the end of 2013, 62 per cent were non-whites, a dramatic increase. Following protests by white firefighers (Clayton 2012), the federal judge issuing the order was under police protection in his home, and the fire commissioner monitored behaviour toward the new graduates in the city's fire stations (Schwirtz 2013). The story continued in 2014 after the election of a new mayor in NYC, Bill de Blasio. His administration accepted culpability, as determined by a federal judge, to the charge that institutional racial biases operated against African American and Latino applicants to the NYFD. And in March 2014 
the city agreed to pay $\$ 100$ million in back pay and benefits to minorities thwarted from joining the city fire department (Santora and Schwirtz 2014).

This sorry tale shows several levels of inequality facing African Americans. First, are the living circumstances - the housing, schooling, health and exposure to integrated institutions- of African Americans, and the question of whether these are meaningfully egalitarian or worn down by racial inequalities? The hopeful recruits grew up in segregated housing and schools experiencing discrimination in employment opportunities, since the fire service recruited in a racially biased way. Second, equal opportunity did not exist for these applicants. The federal agency, the Equal Employment Opportunity Commission, takes complaints about discrimination but is much weaker at enforcement. And in turn this flaunting of basic level playing field principles harmed economic prospects - the denial of occasion to earn income or to accrue savings from income to build household assets. Unions historically bolstered racial inequality and reformed only with federal court activism (Frymer 2003, 2005). Third, plainly equal outcomes were denied to these citizens in such crucial life and wealth determining experiences as salaries and wages, university graduate numbers and in occupational seniority across the public and private employment sectors. This story illustrates why American federal activism matters so much to improving material racial equality. Although federal courts, particularly the Supreme Court, are bellwether friends of racial equality, it was the United States that sued the City of New York alleging its firefighter department violated Title VII of the Civil Rights Act 1964. Finding against the city, the federal judge ruled that, "from 1999 to 2007, the New York City Fire Department used written examinations with discriminatory effects and little relationship to the job of a firefighter to select more than 5,300 candidates for admission to the New York City Fire Academy." The court found that "these examinations unfairly excluded hundreds of qualified people of color from the opportunity to serve as New York City fire-fighters.. constituted 
employment discrimination in violation of Title VII of the CRA of 1964" (United States $v$. City of New York 637 F. Supp. 2d 77, 79 (E.D.N.Y. 2009)).

This sort of saga is far from unique to this occupation or this city (as revealed for example in the extraordinary racial inequalities sustained for almost fifty years after civil rights laws in Local 28 Sheet Metal Workers, exploiting its founding "Caucasians only" covenant. It was under court supervision from the 1970s until 2015 before compensating discriminated against African American members (Swarns 2015)). It underlines both the need for national policy leadership, in this case a federal judge enforcing standards, and for steadfastness through enforcement to achieve significant change. Almost thirty years ago one scholar wrote that to eliminate residential segregation would entail aggressive federal "enforcement of existing laws, enactment of even stronger laws, and further incentives for integration" in housing and beyond (Kain 1986: 116). As New York shows, rights are not self-enforcing in the American polity but require constant monitoring and direction: litigation is not a solution but a necessary element in meaningful federal activism. Kain's remarks about enforcement are pertinent in many policies. For the most part, politicians find it easier to ignore than to engage with the persistence, and economic consequences, of segregation (in housing or schools for instance) which sustains material racial inequality than to face them (Bogira 2013, King and Smith 2011). Any stoppage or disengagement by the American federal government enhances this neglect.

\section{Forms of Forceful Federalism.}

The major laws enacted in the 1960s, including the Civil Rights Act of 1964, the Voting Rights Act of 1965, and to a lesser extent the Fair Housing Act of 1968, are the prototype in creating new standards, statutorily based often with executive order backup, by which equal rights of citizenship and other measures are to be upheld. This is the first form of federal 
activism. These new rights need not just to be pronounced but also to be enforced, which requires other types of American federal action such as judicial orders or deployment of federal personnel. An important aspect of this type of action is the creation of touchstone standards that citizens can expect the federal government to uphold. That it took almost two hundred years from founding and a massive civil rights protest movement struggle to get the standards established is indicative of how precious they are for democratization. In the case of the VRA, US Department of Justice enforcement powers buttressed the new law and regulated its administration.

Coercive state power involves both speedy executive action in response to specific threats and enforcement powers. The executive uses federal authority, powers and resources including the physical force it possesses independently of judicial or congressional challenges. Examples included President Franklin D Roosevelt's executive order establishing a Fair Employment Practices Committee in 1941, covering war industries, President Dwight D Eisenhower's deployment of federalized national guards to Little Rock, Arkansas in October 1957 and Kennedy's dispatch of federal troops to help university desegregation. This type of state power is designed to restrain disorderly behaviour sometimes stirred up by white opponents of racial equality and above all to maintain public order, demonstrating its purported monopoly on the use of legitimate force. In other words it was not necessarily used to enforce the new standards - the Little Rock school closed for a year and in Virginia schools were closed for four years (Bonastia 2012). Nor remarkably were federal troops sent to Selma in 1965 after the local police were filmed on television beating up peaceful civil rights marchers. Such deployments of national guards to quell public disorder are not just historic as Ferguson, Missouri showed in August 2014.

Housing desegregation is an example of an arduous and tortured reform with limited success. These are state-led in that new standards are institutionalized but the federal 
government pushes leadership for the changes onto societal actors, notably communities and state and local governments; new federal funds were provided to finance the reform and a new agency HUD was created. Lacking a coercive edge, and exploiting national executive infirmity, commonly enjoying judicial protection for the weakest version of the reform, white communities and their citizens obfuscate, resist, and dilute the changes. There is often ambiguity about the standards too. For instance, is setting enforceable standards for antidiscrimination in housing rental and buying markets sufficient to achieve integration or is physical federal monitoring essential? The presence of federal marshals after the VRA was passed in 1965 was necessary to enforce the new voting rights. While there has been a steady housing desegregation trend, it is still pretty slight.

Hybrid intervention: The distinction between these three broad types of federal activism is intentionally overdrawn. There are many ways in which they overlap; hybrid forms combine elements of more than one. To effect change requires interventions combining different mechanisms, such as the granting or withholding of federal funding or new federal laws enforced properly. Among examples of these latter is the use of conditional grants by the federal government to enforce compliance with policies. States lose funding if they violate the standards set in the Clean Air Act. To maintain federal highway funding support states must agree to enforce the federal speed limit and minimum drinking ages. Universities' receipt of research funding is tied to getting gender parity in athletic programs. The 2001 No Child Left Behind law, and subsequent modification, ties the distribution of federal education programs to state compliance with accountability requirements. Such use of conditional fiscal incentives is predictably unpopular at the sub-federal level but can be effective.

A coercive executive order frequently overlaps with the manipulation of federal grants to state or local institutions in order to get change. School desegregation got going when federal largesse was withheld or provided, to give ballast to court orders. Some 
segregationists simply rejected federal assistance rather than accept reform, ensuring no reform unless the national government failed to apply coercion which is mostly didn't.

Because coercion, standard setting and fostering change overlap and their use fluctuates from purposeful state policy to contingency control of spiralling crises their rationales and effects for material racial equality are mixed and often messy. At least three sorts of purposes can be discerned and each type of action promotes them to differing degrees. The immediate and long term erosion of discriminatory behaviour and institutions informs both standard setting and societal led reforms, designed to effect forceful antidiscrimination in workplaces, health care and housing to reduce material racial inequality. Setting a level playing field through such measures as affirmative action or desegregating schools and housing shapes both short term coercive interventions and the long term state led societal change. And making America racially integrated through the breakdown of the separate worlds built by segregation infuses the aims of all policy interventions in the 1960s and 1970s.

\section{$\underline{\text { Table } 1}$}

Mechanisms of federal activism.

Forms of Federal

Policy instruments.

Intervention.

Coercion.

Deployment of national guards/military

Fiscal largesse granted or withheld.

Direct monitoring of local practice. (eg federal monitors enforcing VRA)

Standard setting. Agency creation to issue and monitor regulations (eg EEOC)

Seeking court orders setting standards (eg school integration plans). 
Federal department conducted investigations

(eg Justice Dept review of Ferguson and Baltimore city police departments)

State-led reform

Obligations included in federal grants to states and cities (eg HUD duty to fair housing).

Sanctioning/granting funds for integrated housing

Fiscal intervention.

Making receipt of federal funding conditional on compliance with specific goals. A key resource of the administrative-regulatory state.

Crises, protests and federal activism.

Crises drive federal responses to racial inequality and conflict. Crisis is rarely an objective condition. A state permeated with racial inequality is vulnerable to both endogenous and exogenous shocks and crises. Getting the federal government active to enforce civil rights is a fundamental aim of reformers in a fragmented and divided federal political system, which means changing the mentality of the State. Securing citable and enforceable standards, such as the right to vote, can't depend on local discretion or it will be denied to some of the citizens racialized as African American by their oppressors, racialized as white (Fields 1990). Through active enforcement of federal laws, American society should be transformed rather than merely modified, the scale of this transformation and its solidity can only be judged by subsequent tests of the new legislation.

Protest fuelled crises are efforts by excluded, discriminated against and underrepresented groups of citizens to influence American federal policy to address inequalities of citizenship rights. The civil rights movement is the most important such mobilization in US history. Protest drove the civil rights movement, ranging from the efforts to desegregate 
cities, to achieve voting rights and the legal powers to challenge labour market discrimination. Martin Luther King Jr purposefully orchestrated the Selma marches in 1965 against voting disenfranchisement "to arouse the federal government" into some sort of action and response (quoted in Valelly 2004: 193), and later called the new civil rights laws "legislation written in the streets" (King 1965). Although such protests appeared partly spontaneous and therefore powerfully disruptive of the existing segregationist order (Piven 2006), in fact such protests built on decades of collective engagement and organization through numerous institutions notably churches, and such rights seeking organizations as trades unions and the network of March on Washington branches (Aldon 1984: 277-78, McAdam 2009). Building a protest movement is a formidable task (Harris 2014, Payne 2007).

These protest fuelled crises feed into two familiar mechanisms of national state building in the United States, war making (the Revolutionary War, Civil War and Second World War are instances of this process) and social mobilization (abolitionists, progressives at the turn of the twentieth century, unemployed workers' movements, generations of civil rights reformers, immigration reformers and feminists). Of course there is no automatic conveyance or transmission from these 'crisis' events to state action, but both have proved to be such stimulants of national state building through emergency or reform historically; the reason for getting on the agenda is something scholars grapple to specify. It is for instance uncertain whether protest fuelled mobilization will reach a threshold sufficient to generate federal responses and what is required. In 1923, the Dyer bill to empower the federal government to enact anti-lynching laws came within a couple of votes of success in Congress and then failed. That the Dyer bill reached this point resulted from sustained and widespread social protests about the scale of lynching of African Americans in the US over the previous half century. The example underscores Dara Strolovitch's observation that "bad things which 
happen to marginalized groups evade crisis framings and are instead normalized and particularized within dominant institutions" (2013: 169). In her analysis of why the Great Depression, Great Recession and subprime mortgage implosion became crises winning national political attention, Strolovitch underlines the "troubling premise" that these became crises without any reference to such enduring trends as income inequality and patterns of racial segregation. And persistent problems such as unemployment or discrimination commonly lack the sort of objective crisis status or successful mobilization to become treated as aberrations for urgent attention.

This discussion conveys the difficulty of specifying the mechanisms which render crises un-ignorable priorities for policy makers. But when the transition does occur, crises represent a point of no return. They signal the collapse or near collapse of the existing order and that everything has to change. Pearl Harbor meant that the US was at war and that most of American society would be subordinated to that condition until the conflict ended. Little Rock, televised nationally, forced (a reluctant) American federal intervention to enforce desegregation - little followed automatically from this engagement but a threshold of national responsibility in respect to enforcement was reached which dominated national politics until enforcement legislation was enacted in the next decade. Crucial to this shift is the way in which the American federal government facilitates or hinders responses. Sending federal troops to Little Rock, Arkansas in 1957 in response to the efforts by opponents of school desegregation to prevent integration made America's racial hierarchy and weak civil rights a global issue and seemed to signal a national commitment to addressing inequality (Dudziak 2000).

Desegregation of schools occurred under court ordered integration mandates. These orders generated significant changes in the South by the 1970s but then the trend stalled (Clotfelter 2004; Reardon et al 2012). This stalling is important because inter race contact of 
the sort achieved by integrated schools is a crucial part of making desegregation more than just symbolic - it provides an opportunity for shared experience and future exchange which erodes into the social boundaries sustaining segregation.

A revolution to harness the federal state.

Contentious politics is defined by Tilly and Tarrow (2007) as involving "interactions in which actors make claims bearing on someone else's interests, leading to coordinated efforts on behalf of shared interests or programs, in which governments are involved as targets, initiators of claims, or third parties. Contentious politics thus brings together three familiar features of social life: contention, collective action, and politics" (2007: 4). For 'contentious politics' scholars, social movements are just one category of popular struggle within a broad spectrum of actions. Their concept of 'government' (p5) or the state is too weak to grasp the scale of civil rights revolution demanded in the US; they cast the State as one actor rather than a dominant structurally advantaged institution which reformers seeks to harness, control and direct as the means for ensuring enforcement of rights. Civil rights protesters did not simply fire up contentious politics since its leaders and activists had as a revolutionary aim to bring the national state into service as an agency of equal standards. Thus writing in 1965, a year after the Civil Rights Act, Martin Luther King Jr. underlined this aim: "in their furious combat to level walls of segregation and discrimination, Negroes gave primary emphasis to their deprivation of dignity and personality. Having gained a measure of success they are now revealed to be clothed, by comparison with other Americans, in rags. They are housed in decaying ghettoes and provided with a ghetto education to eke out a ghetto life.... Only when they are in full possession of their civil rights everywhere, and afforded equal economic opportunity, will the haunting race question finally be laid to rest" (1965: 6). 
For the sociologist Aldon Morris (1984), the post-1940s civil rights movement is a form of protest which draws upon but significantly develops a tradition of organized black protest against white supremacy and racially discriminatory political institutions such as disenfranchisement and segregation (see Payne 2007). It featured direct confrontation with white racist officeholders and law enforcement officers and, later under King's charismatic guidance, incorporated nonviolent methods into the existing organizational structures and groups including SCLC, CORE and SNCC. The economic, political and personal dimensions of racial domination - what Morris calls the tripartite system - were tackled by the civil rights movement from the 1950s. Amenta et al (2010: 288) stress the role of 'sustained political action" in any social movement's struggles: this is useful since keeping the momentum going for protest is intensely difficult (Harris 2014).

A decline in protest momentum coincided with the rise of neoliberal state minimalism and deregulation after 1981 (marked with President Reagan entering the White House), and major federal welfare reductions in 1988 and 1996 (Spence 2015). Increased incarceration and a tougher language of law and order regime - nominally a response to social disorder again originating in the 1980s further eroded civil rights protests (Miller 2014).

Absent since the early 1980s is sustained black insurgency demanding federal activism of the scale observable during the 1960s. This absence comes from a variety of reasons including: the political dominance of colour blind rhetoric in discourse about material racial inequality (King and Smith 2014); the increased racial polarization of the electorate between whites and black voters especially about ameliorative federal policy (Tesler 2016); the dilution of national civil rights organization and activism, despite Jesse Jackson's important presidential nomination bids, until the emergence of Black Lives Matter; the rise of a deracialization strategy, contra Jackson, amongst other African Americans seeking local, state or national electoral offices (Harris 2012, Reed 1986); the reluctance of President 
Obama to become a leader of African American interests (Harris 2012, King and Smith 2011); and the differential racial impact of the 2008 financial crisis (Jacobs and King 2016). Black Lives Matters marks a turning point.

\section{From Enactment to Enforcement to Resistance: How the State is stopped.}

Aside from engaging in pernicious tactics to disrupt and discredit civil rights leaders - the FBI approach in the 1960s - opponents of federal activism and of civil rights reform have worked to reabsorb protestors, by marginalizing into routinized politics, and to make the tint of those routine politics rhetorically favourable to anti-reform positions. The color blind mantra and 'incurability of racial inequality' mentality play this role. Re-absorption means undercutting the revolutionary challenge of civil rights to restructure state laws and to seize national authority to enforce policies for racial equality. It means avoiding the contradiction displayed by opponents of civil rights enforcement in their willingness to endorse federal activism in other policies. These latter expansionary policies include the growth of the FBI, federal narcotics laws and expanded prisons, national defence, immigration policy and a range of universal income support programs such as social security, medicare and Affordable Health Care garner electoral support.

Several factors act to reverse forceful federalism in civil rights (table 2). Each of the mechanisms in Table 1 is vulnerable to subversion, not least from simple fatigue overtaking national law makers and regulators. More purposefully, a new administration can shift priorities and resources away from federal civil right activism. This reconfiguration occurred in both 1981 and 2001 when Ronald Reagan and George W Bush respectively took control of the executive, to divert enforcement of civil rights and encourage the Justice Department's civil rights division to attend to issues other than racial discrimination. 
Table 2.

The resistance to and dilution of federal activism.

Violence and civil disobedience. Whites mobilize to stop schools integrating or to prevent housing integration. The exercise or threat of violence defines America's racial hierarchy.

Judicial dilution. Celebrated for Brown and some other school cases, since the mid-1970s key decisions have diluted set asides, affirmative action, school integration plans, and voting rights.

Infirm agency powers. Many federal agencies established to advance equality endure congressional attacks weakening them; are under resourced; and lack a clarity of mission.

Bias against action. Federal activism often a short term un-sustained response to crisis, with little policy between protests;

Anti-Government. The successful political assault on both the legitimacy and efficacy of federal activism as an instrument of governance.

First, civil disobedience and violence toward black protesters and law enforcement officers is a powerful and effective tool of resistance used by white opponents of reform. Little Rock closed its school for a year in response to the crisis and inflicted immense costs on the African American families. In Virginia's Prince Edward County school district officers opted to close the public schools for five years rather than desegregate them, and made no provision at all for the harmed African American children but did for the white pupils (Bonastia 2012). Thus, these crises shook the system but did not produce institutional persistence or radical reform - rather a debilitating mixture of weakly enforced (or not enforced) national directives which dragged the segregation crisis into the next decade and led eventually to new laws, often in the wake of political violence including assassinations. 
Second, since the mid-1970s the Supreme Court has issued decisions mostly weakening the conditions for enforcement of federal measures designed to improve material racial equality, diluting both affirmative action and set aside employment quotas for example (table 3).

Table 3.

Set asides and other aa measures.

Washington v. Davis (1976): Court permitted use of procedures \& written personnel tests in DC police dept, thereby weakening disparate impact criterion.

Fullilove v. Klutznik (1980): $10 \%$ rule constitutional.

Ward's Cove (1989): court made it harder for plaintiffs to demonstrate disparate impact claims by weakening 'business necessity' standard.

City of Richmond v. J A Croson Co (1989): strict scrutiny standard.

Adarand Constructors Inc. v Pena (1995): 'strict in theory but not fatal in fact."

"Mending not ending" affirmative action - Clinton Presidency.

Alexander v. Sandoval (2001): weakened disparate impact in CRA Titlle VI, in federally funded activities.

Ricci v. DeStefano (2009): court rejected use of disparate impact threat and argued that New Haven overturning of test results violated Title VII discrimination. Majority Justices hint at wider attack on disparate impact standard.

Third, the federal agencies charged with enforcing equal opportunity, antidiscrimination and desegregation have lacked ballast or been quickly side-tracked. The lamentable HUD record on ensuring affordable racially integrated housing is an instance. Indifferent enforcement and reversals in the 1980s led to the rise of second generation barriers as sources of discrimination in housing, labour and education markets and the nondurability of earlier measures - for instance, the decline in the number of African American students at public universities. These second generation barriers, and phenomena such as the 'neighbourhood effects' associated with the persistence of communities of concentrated 
disadvantage, arise because of weakly enforced and under resourced reforms of the sort lobbied for by civil rights reformers (Desmond 2016). State stoppage is detrimental to the material racial equality agenda.

Fourth, federal engagement with racial inequality is fitful, commonly inattentive in the absence of social protest. Combined these factors produce a bias toward non-permanent reform and weak political support for reform when enacted. These outcomes contribute significantly to democratic dysfunction - measured in the weak progress toward material racial equality - and distinguish US experience comparatively, since in most political systems once enacted policy endures. Congress's deep ideological division and partisan polarization exacerbate the challenge of passing and sustaining policy.

Finally, a long-term erosion of trust in the federal government amongst American voters coincides with the rise of federal activism. Public support in the capacity of federal agencies has been under relentless assault from politicians since the 1980s, with President Ronald Reagan conveying this excoriating view in his popular mantra, "I'm from the federal government and I am here to help you." This negative anti-Washington approach drove the 'contract with America' Gingrichism in the 1990s.

In the US case policy institutionalization is harder to achieve because of the fragmentation of the political system, and because the opportunities for opponents to block a policy and to continue to seek its reversal. Thus the Brown decision in 1954 ruling separate and unequal schools unconstitutional had no immediate impact on the election of members to school district boards throughout the country. These boards remained in charge of the schools in the continuing separate but equal system and which were now supposed to be desegregated. In most cases the ruling was flagrantly ignored. Referring to Georgia's DeKalb County School System response, the Supreme Court observed in Freeman v. Pitts that 
“interpreting 'all deliberate speed' as giving latitude to delay steps to desegregate, DCSS took no positive action toward desegregation until the 1966-1967 school year, when it did nothing more than adopt a freedom of choice transfer plan."

The challenges which can be mobilized through negative feedback are more common and effective in the fragmented US polity than in other advanced industrial democracies. An obvious example is the impact of judicial challenges (table 3). These can dilute or abrogate policies, as has occurred in set aside programs, the federal scheme to make sure African American and Latino employees are hired for some federal contract based work.

Institutionalization matters in the drive against material racial inequality because it helps explain why it is so difficult to make liberal reforms durable. Retaining momentum for controversial policy decisions, ensuring that actors below the federal level will commit to policy delivery, and maintaining support through new electoral cycles are demanding tasks. Although this complexity produces some bias toward inertia and the status quo and policy persistence - what political scientists see as a form of path dependence - the deepening ideological polarization in the United States about race, since the Supreme Court started attacking policies designed to reduce material racial inequalities in the mid-1970s (notably, in the Milliken and Bakke judgments), and the partisan political elite increasingly divided in roll call votes and arguments from the 1990s (including about racial inequality), has privileged federal lethargy above intervention.

\section{Conclusion: Dysfunction as a crisis of federal enforcement.}

The struggle for material racial equality and civil rights in the United States is associated with key periods of dramatic events or crises - such as war or a sustained public disorder or white resistance so egregiously violent and publicized as to be un-ignorable by the federal executive. These responses sometimes generated significant political reform. Two less 
observed aspects of these reforms however are their comparative rarity - the US polity is an immensely hard one for reformers to secure fundamental change in or to create new policy regimes (witness the 1880s to 1960s era of legal segregation of African Americans throughout the country) as several scholars note (Piven 2006, Stepan and Linz 2011). This sclerotic characteristic is exaggerated by bureaucratic fragmentation within and between agencies and levels of government, the frequent timidity of some elected federal officeholders to undertake national reform; and the difficulty of maintaining and sustaining major reforms once initiated. These factors combine to produce tepid enforcement of proequality policies which in turn exacerbates the sources of material inequality. This democratic dysfunction exploded into the 2016 presidential campaign when the Republican nominee Donald Trump characterized inner cities as racially dangerous ghettos.

In advancing the goal of material racial inequality, furthermore, presidents and civil servants sit on one side in America's bitter partisan and ideological polarization (Tesler 2012, 2016). This polarization is found across the nation from presidential division down to mayoral and school board elections. Opponents to the use of federal resources to address legacies of racial inequality form one side of this divisive politics. This coalition opposing race targeted, or what Supreme Court Justice Sonia Sotomayor calls 'race sensitive,' measures is powerful and politically effective and indeed dominates the national mentality about the sources and meaning of racial inequality (King and Smith 2011, 2014). The importance of coalitions for durable policy change is emphasized by Patashnik and Zelizer who write that, "the issue.. is not only whether the interests that originally prompted a reform will endure, but whether a reform sustains the coalitions that brought it about or causes new coalitions to emerge after enactment" (2013: 1074). The embeddedness of social security after its enactment in 1935 is a favourite example of how a law's content and form of delivery (Roosevelt tied it to the tax system) fanned an enduring coalition of interests 
(Campbell 2012; Morgan and Campbell 2013). But it is a rare instance of durability.

Sustaining coalitions from grass roots protest movements has proved tough. Even a law as symbolic and politically important as the Voting Rights Act confronted sustained critique during its various renewals in Congress and, since 2008, the combination of partisan polarization and anti-race conscious politicians has remarkably made voting laws a salient electoral issue (Berman 2015). Such changes in partisan divisions are a reminder that even within a polity resistant to change and with significant incremental institutional biases linear paths of development are not automatic.

The aim of civil rights reformers to secure new laws onto the statute books - the enactment phase of law making - constitutes a distinct step from subsequent enforcement, what Patashnik and Zelizer call the post enactment stage of a policy's life. Successful postenactment requires not only resource mobilization, targeting benefits and generating positive feedback but also dis-abling critics of reform and change (Palashnik and Zelizer 2013: 1076). New policies often lack positive feedback because of the success of opponents in criticizing them or poor design at the enactment stage, though even poor design can be overcome during implementation with careful decisions about how to displace critics and how to make the law appealing to voters. The experience of numerous policies intended to advance racial equality, such as affirmative action, shows little success in securing supportive policy feedback but acres of negative responses (Hutchings 2009, Tesler 2016).

The limitations of policy designed to address racial inequality and the frequently weak and often negative policy feedback mechanisms stand out as sources of continuing inadequate enforcement and therefore persistent black-white achievement and income disparities. Because getting to policy enactment was so politically difficult the laws often lacked precision or strident enforcement measures - if included these latter would have given equality opponents a target. The CRA of 1964 was circumspect about what if any remedial 
measures to address historical injustices were necessary to create a level playing field (as President Johnson soon acknowledged in his famous Howard University Commencement speech in June 1965 when he declaimed that 'freedom is not enough' as the basis for authentic and measurable equality). It fell to agencies such as the EEOC to design and warily enforce measures to promote material racial equality. The EEOC had a good first decade of effective enforcement (Dobbin 2009) but now falters under the weight of tightened federal appropriations and Republican colour-blind hostility. An exception to such enforcement weakness is the VRA of 1965 which did include detailed implementation measures to get voting rights established. Finally, if mandated in a judicial decision - such as an order to desegregate schools - enforcement is often weak or episodic because it requires the federal government to act to see off public opposition. Such federal activism - other than as emergency band aid response - is rare. The saga of school integration efforts after Brown in 1954 to recent Supreme Court rulings exemplifies this pattern of weak enforcement.

The upshot of insufficient federal activism and enforcement is democracy with persistent and profound racial inequalities. There is certainly a significant African American middle class in the United States but the persistence of substantial black-white disparities in household income and wealth, home ownership, education achievement, health and mortality trends, exposure to environmental pollutants and treatment in the criminal justice system points to structural barriers sustaining racial inequality. As demonstrated in the enforcement of such policies as the right to vote or workplace anti-discrimination, equality strategies bolstered by forceful federalism can break these entrenched inequalities. The absence of such focused federal engagement guarantees discontent, protest and enduring racial polarization. 


\section{References}

Amenta, Edwin, Neal Caren, Elizabeth Chiarello and Yang Su. 2010. "The Political Consequences of Social Movements." Annual Review of Sociology. 36: 287-307.

Anderson, Carol. 2016. White Rage: The Unspoken Truth of Our Racial Order. New York: Bloomsbury.

Berman, Ari. 2015. Give Us the Ballot. New York: Farrar, Straus and Giroux.

Bogira, Steve. 2011. "Separate, Unequal and Ignored.” Chicago Reader. February 10.

Bonastia, Christopher. 2012. Southern Stalemate: Five Years without Public Education in Prince Edward County, Virginia. Chicago: U of Chicago P

Campbell, Andrea Louise. 2012. "Policy Makes Mass Politics.” Annual Review of Political Science. 15: 333-51.

Campbell, Michael and Heather Schoenfeld. 2013. "The Transformation of America's Penal Order: A Historical Political Sociiology of Punishment." American Journal of Sociology. 118: 1375-1423.

Charles, Camille Zubrinsky. 2001. "Processes of racial residential segregation," in Urban Inequality: Evidence from Four Cities. Edited by Alice O'Connor, Chris Tilly and Lawrence D. Bobo. New York: Russell Sage Foundation.

Clayton, James. 2012. "Affirmative Action in Action: Overhaul of the Fire Department of New York Hiring Practices." The Observer October 30.

Clotfelter, Charles T. 2004. After Brown: The Rise and Retreat of School Desegregation. Princeton: Princeton University Press.

Coates, Ta-Nehisi. 2014b. "The Case for Reparations.” Atlantic Monthly. June.

Davis, Gordon J. 2015. "What Woodrow Wilson Cost My Grandfather." New York Times. November 24.

Desmond, Matthew. 2016. Evicted: Poverty and Profit in the American City. New York: Crown.

Dimick, Justin et al. 2013. "Black Patients More Likely Than Whites to Undergo Surgery at Low-Quality Hospitals in Segregated Regions." Health Affairs. 32: 1046-53.

Dobbin, Frank. 2009. Inventing Equal Opportunity. PUP

Dudziak, Mary. 2000. Cold War Civil Rights. Princeton: Princeton University Press. 
Ellen, Ingrid Gould 2007. "How Integrated Did We Become during the 1990s?" in John Goering ed. Fragile Rights within Cities: Government, Housing, and Fairness. Lanham MD: Rowman and Littlefield.

Fields, Barbara Jeanne. 1990 "Slavery, Race and Ideology in the United States of America," New Left Review No 181: 95-118.

Fortner, Michael Javen. 2015. Black Silent Majority: The Rockefeller Drug Laws and the Politics of Punishment. Cambridge MA: Harvard University Press.

Francis, Megan Ming. 2014. Civil Rights and the Making of the Modern American State. New York: Cambridge University Press.

Frymer, Paul. 2003. “Acting when elected officials won't: Federal courts and civil rights enforcement in U.S. labor unions, 1935-85." American Political Science Review 97: 483-99.

Frymer, Paul. 2005. "Racism revised: Courts, labor law and the institutional construction of racial animus." American Political Science Review. 99: 373-387.

Garland, David. 1010. Peculiar Institution: America's Death Penalty in an Age of Abolition. New York: Oxford University Press.

Gerstle, Gary. 2015. Liberty and Coercion. Princeton: Princeton University Press.

Gillesipie, Andra. 2012. The New Black Politician. New York: NYU Press.

Gillion, Daniel Q. 2016. Governing with Words: The Political Dialoge on Race, Public Policy and Inequality in America. New York: Cambridge University Press.

Glaeser, Edward and Jacob Vigdor 2012. "The End of the Segregated Century: Racial Sepaation in America's Neighborhoods 1890-2010.” Washington DC: Manhattan Institute Civic Report No 66.

Goering, John M. ed. 1986. Housing Desegregation and Federal Policy. Chapel Hill NC: University of North Carolina Press.

Gottschalk, Marie. 2006. The Prison and the Gallows: The Politics of Mass Incarceration in America. New York: Cambridge University Press.

Gottschalk, Marie. 2014. Caught: The Prison State and the Lockdown of American Politics. Princeton: Princeton University Press.

Greer, Christina. 2013. Black Ethnics: Race, Immigration and the Pursuit of the American Dream. New York: Oxford University Press.

Harris, Fredrick C. 2012. The Price of the Ticket. New York: Oxford University Press. 
Harris, Fredrick C. 2014. "Will Ferguson be a moment or a movement?" Washington Post, August 22.

Hochschild, Jennifer. 1999. "You Win Some, You Lose Some...: Explaining the Pattern of Success and Failure in the Second Reconstruction," in Morton Keller and R Shep Melnick eds. Taking Stock: American Government in the Twentieth Century. New York: CUP.

Hutchings, Vincent L. 2009. "Change or More of the Same? Evaluating Racial Attitudes in the Obama Era," Public Opinion Quarterly. 73: 917-942.

Iceland, John, Daniel H Weinberg and Erika Steinmetz. 2002. Racial and Ethnic Residential Segregation in the United States: 1980-2000. Washington DC: US Census Bureau.

Jacobs, Lawrence R. and Desmond King. 2016. Fed Power: How Finance Wins. New York: Oxford University Press.

Johnson, Kimberley S. 2015. "The Color Line and the State: Race and American Political Development." In The Oxford Handbook of American Political Development editd by Richard Valelly, Suzanne Mettler and Robert Lieberman. New York: Oxford University Press.

Kain, John F. 1986. “The Influence of Race and Income on Racial Segregation and Housing Policy," in Goering.

Kato, Daniel. 2015. Liberalizing Lynching. New York: Oxford University Press.

King, Desmond. 2007. Separate and Unequal: African Americans and the US Federal Government. New York: Oxford University Press.

King, Desmond and Robert C Lieberman 2009. "Ironies of State Building: A Comparative Perspective on the American State," World Politics 61: 547-588.

King, Desmond, and Rogers Smith. 2011. Still a House Divided. Princeton: Princeton University Press.

- - 2014. "Without Regard to Race: Critical Ideational Developments in Modern American Politics." Journal of Politics 76: 958-71.

King Jr., Martin Luther. 1965. “Let Justice Roll Down.” The Nation. June.

Lacey, Nicola and David Soskice. 2015. "Crime, punishment and segregation in the United States: The paradox of local democracy." Punishment \& Society. 17: 454481 
Logan, John R. and Brian J. Stults. 2011. "The Persistence of Segregation in the Metropolis: New Findings from the 2010 Census." Census Brief prepared for Project US2010.

Mazumder, Bhashkar. 2014. "Black-white differences in intergovernmental economic mobility in the United States." Economic Perspectives, 1Q: 1-10.

McAdam, Doug. 1982. Political Process and the Development of Black Insurgency, 19301970. Chicago: University of Chicago Press.

McAdam, Doug. 2009. "The US Civil Rights Movement: Power from Below and Above, 1945-70." In Civil Resistance and Power Politics. Eds Adam Roberts and Timothy Garton Ash. Oxford: OUP.

McCarty, Nolan. 2015, "Polarization and American Political Development." In The Oxford Handbook of American Political Development editd by Richard Valelly, Suzanne Mettler and Robert Lieberman. New York: Oxford University Press.

Miller, Lisa L. 2014. "The (Dys)Functions of American Federalism.” Tulsa Law Review. 49: 266-278.

Miller, Lisa L. 2016. The Myth of Mob Rule: violent crime and democratic politics. New York: Oxford University Press.

Morgan, Kimberly and Andrea L Campbell. 2012. The Delegated Welfare State. New York: Oxford University Press.

Morris, Aldon D. 1984. The Origins of the Civil Rights Movement. New York: Free Press.

Murakawa. Naomi. 2014. The First Civil Right: How Liberals Built Prison America. New York Oxford University Press.

National Urban League. 2014. One Nation Underemployed: Jobs Rebuild America. Washington DC: National Urban League.

Parks, Rosa. 1992. My Story. New York: New York.

Patashnik, Eric M. and Julian E. Zelizer. 2013. "The Struggle to Remake Politics: Liberal Reform and the Limits of Policy Feedback in the Contemporary American State." Perspectives on Politics. 11: 1071-1087.

Payne, Charles M. 2007. I've Got the Light of Freedom. Berkeley: University of California Press.

Peterson, Paul. 1981. City Limits. Chicago: University of Chicago Press.

Pew Research Center. 2012. Trends in American Values 1987-2012. Washington, D.C.: http://www.people-press.org/files/legacy-pdf/06-04-12 Values Release.pdf 
Pinderhughes, Dianne. Ed. 2014. Uneven Roads: An Introduction t US Racial and Ethnic Politics. Washington DC: Sage CQ Press.

Piven. Francis Fox. 2006. Challenging Authority: How Ordinary People Change America. Boulder CO: Rowman \& Littlefield Publishers.

Price, Melanye. 2016. The Race Whisperer: Barack Obama and the Political Uses of Race. NY: NYU Press.

Reardon, Sean F. and Kendra Bischoff. 2011. "Growth in Residential Segregation of Families by Income, 1970-2009." Census Brief prepared for Project US2010.

Reardon, Sean F., Elena Tej Grewal, Demetra Kalogrides and Erica Greenberg. 2012. "Brown Fades: The End of Court-Ordered School Desegregation and the Resegregation of American Public Schools." Journal of Public Policy Analysis and Management 31: 876-904.

Reed Jr, Adolph L. 1986. The Jesse Jackson Phenomenon. New Haven: Yale University Press.

Santora, Marc and Michael Schwirtz. 2014. "City Settles Lawsuit Accusing Fire Dept. of Racial Bias.” New York Times. March 19.

Schwartzman, Paul. 2016. "Why some whites are waking up to racism." Washington Post. August 3.

Schwirtz, Michael. 2013. "For New York City Fire Department, More Diversity Amid Tension," New York Times. December 4.

Shapiro, Thomas M. 2004. The Hidden Cost of Being African American. New York: Oxford University Press.

Shapiro, Thomas M., Tatjana Meschede and Laura Sullivan. 2010. "The Racial Wealth Gap Increases Fourfold." Institute on Assets and Social Policy. Brief. May.

Shapiro, Thomas, Tatjana Meschede and Sam Osoro. 2013. "The Roots of the Widening Racial Wealth Gap: Explaining the Black-White Economic Divide." Institute on Assets and Social Policy. Brief. February.

Sheingate, Adam. 2009. "Why Can't Americans See the State?" The Forum 7: 4.

Spence, Lester. 2015. Knocking the Hustle: Against the Neoliberal Turn in Black Politics. New York: Punctum books.

Stepan, Alfred and Juan J. Linz. 2011. "Comparative Perspectives on Inequality and the Quality of Democracy in the United States." Perspectives on Politics 9: 841-856. 
Stout, Christopher. 2015. Bringing Race Back In: Black Politicians, Deracialization and Voting Behavior in the Age of Obama. Charlottesville: University of Virginia Press.

Strolovitch, Dara Z. 2013. "Of Mancessions and Hecoveries: Race, Gender, and the Political Construction of Economics Crises and Recoveries." Perspectives on Politics. 11: 167-177.

Swarns, Rachel L. 2015 “Minority Sheet Metal Workers in New York Get Back Pay After Decades of Bias," New York Times. December 20.

Tate, Katherine. Ed. 1994. From protest to politics: the new Black voters in American elections. Cambridge MA: Harvard University Press.

Tate, Katherine. 2003. Black faces in the mirror: African Americans and their representatives in the US Congress. Princeton: Princeton University Press.

Tesler, Michael. 2012. "The Spillover of Racialization into Health Care: How President Obama Polarized Public Opinion by Racial Attitudes and Race." American Journal of Political Science. 56: 690-704.

Tesler, Michael. 2016. Post-Racial or Most-Racial?: Race and Politics in the Obama Era. Chicago: University of Chicago Press.

Theoharies, Jeanne. 2013. The Rebellious Life of Mrs Rosa Parks. Boston: Beacon Press.

Thurston, Chloe. 2015. "Policy Feedback in the Public-Private Welfare State: Citizens Advocacy Groups and the Expansion of Access to Government Homeownership Programs." Studies in American Political Development 29: 250-67

Tilly, Charles and Sidney Tarrow. 2007. Contentious Politics. Boulder: Paradigm Publishers.

Wright, Gavin. 2013. Sharing the Prize. Cambridge MA: Harvard University Press.

Wright Rigueur, Leah. 2015. The Loneliness of the Black Republican: Pragmatic Politics and the Pursuit of Power. Princeton: Princeton University Press. 